\title{
Perspektif Baru Politik Luar Negeri China dalam Konstelasi Politik Global: Resensi Buku
}

\author{
Hardi Alunaza \\ Universitas Tanjungpura
}

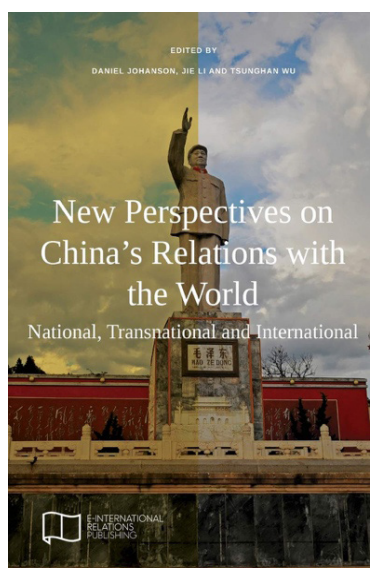

Judul
Penyunting
Penerbit
Cetakan
Tebal

: New Perspective on China's Relations with the World

: Daniel Johanson, Jie Li, dan Tsunghan WU

: International Relations Publishing, Bristol

: 2019

: 197 halaman

Seiring peran dan pengaruh China terhadap banyak negara di dunia semakin berkembang, dipandang perlu untuk memahami bagaimana perspektif China terhadap hubungan luar negerinya dengan negara lain dalam konstelasi politik global. Hasil tinjauan buku ini diharapkan dapat bermanfaat untuk mengeksplorasi tren dan tema baru dalam kebijakan luar negeri China. Selain membuka peluang baru untuk penelitian, buku ini diharapkan dapat menambah wawasan bagi para stakehorlder yang memiliki peran strategis dalam proses formulasi dan kebijakan luar negeri di Indonesia. Buku ini secara spesifik di bagi menjadi tiga bagian. Pertama, penyunting dalam buku ini menjelaskan mengenai isu nasional dalam politik domestik China. Bagian kedua, melihat bagaimana konsep dan kekuatan individu dapat mempengaruhi kekuasaan. Serta, melihat bagaimana interaksi China dengan negara lain baik di kawasan maupun di panggung dunia internasional. Ketiga komponen dalam penjelasan buku ini memberikan gambaran umum mengenai banyaknya perspektif baru tentang interaksi dan aktivitas China dalam formulasi politik luar negerinya dengan negara-negara di dunia.

Bagian pertama buku ini menjelaskan empat bab kerangka isu nasional dalam politik domestik China. Di antaranya isu mengenai etnis minoritas Tibet dan Uighur, pembangunan demokrasi di wilayah Delta Sungai Mutiara, dan isu terkait Hong Kong. Pada bab-bab ini, penulis membahas mengenai keamanan China dan sarana yang digunakan oleh Partai Komunis China dalam mengelola dan memanfaatkan ketegangan dalam negeri. Atas dukungan transformasi sosial 
komprehensif yang dibawa oleh modernisasi dan reformasi politik ekonomi dalam beberapa dekade terakhir, China dinilai tidak hanya menikmati peran besar dan kesuksesan di panggung politik dunia, tetapi juga mendapatkan pengakuan dari Beijing akan kekuatan yang dimiliki oleh China dalam menjalin hubungan luar negeri dengan negara lain.

Bagi politik domestik China, integritas bangsa dan konsolidasi etnis merupakan dua konsep yang sama-sama harus saling diperkuat. Bagi China, apabila konsolidasi di antara semua kelompok dapat tercapai, maka integritas nasional akan dapat terbentuk dan China mampu maju sebagai negara yang bergerak bersama menuju kemakmuran. Bagi China, integritas nasional harus dapat mengacu kepada tiga latar belakang sejarah. Pertama, konsep integritas besar bangsa China yang sudah dibangun sejak Dinasti Qin. Kedua, integritas dapat diperkuat melalui interaksi etnis selama ribuan tahun. Ketiga, perlawanan terhadap imprealis yang berhasil menyatukan masyarakat Tionghoa secara nasional.

Bagian kedua dalam tulisan ini juga menerangkan empat bab yang menjelaskan mengenai isu transnasional dan keunikan politik luar negeri China. Investigasi Tony Tai-Ting Liu memproyeksikan diplomasi publik yang digambarkan oleh China adalah dengan memanfaatkan kisah yang baik dalam perjalanan politik China dan konsep'China Dream' yang digunakan untuk mengatasi isu terkait penyebaran 'teori ancaman China' juga sebagai upaya meningkatkan citra China. Pada bagian kedua juga dijelaskan mengenai kontribusi dari adanya Institut Konfusius dan Kebudayaan China serta unit yang berhubungan langsung dengan upaya diplomasi publik yang dilakukan oleh China. Hasil dari diplomasi publik yang dilakukan oleh China adalah sebagai usaha untuk menjauhkan diri dari bayangan terhadap negara-negara di dunia atas kenyataan status China yang dianggap sebagai ancaman. Lebih dari itu, China berusaha hadir sebagai negara yang ramah dan cinta damai.

Contoh dari proyek yang digunakan China untukmemengaruhiopini publik mancanegara adalah proyek kereta cepat. Agenda ini tidak hanya menggambarkan keuntungan yang diperoleh China dari sisi ekonomi, tetapi juga bertujuan untuk membentuk kembali tatanan politik dunia yang berpihak pada China. Belt dan Road Initiative serta kereta cepat buatan China adalah agenda yang diluncurkan Pemerintah China untuk menguatkan posisi China sebagai aliansi bagi negaranegara di dunia melalui konstruksi dalam bidang infrastruktur. Kedua proyek besar tersebut juga dapat dipergunakan untuk membendung tekanan negaranegara di dunia khususnya sebagai penghubung kepentingan China terhadap negara-negara di Asia, mengubah dinamika kekuatan regional, menimbulkan kekuatan kontra hegemoni yang melawan sistem liberal Barat. Hingga akhirnya, kedua proyek tersebut mampu mendirikan lembaga internasional baru yang sesuai dengan kepentingan ekonomi dan politik China. Bagi tatanan global, keberhasilan China dapat memberikan potensi dukungan untuk kerangka kerja sama global baru dimana keterlibatan China bisa membendung elit yang ada atau juga memungkinkan adanya perubahan.

Bagi perkembangan kerangka diplomasi, China juga terlibat aktif dalam meningkatkan hubungan baik terhadap Afrika. Hal itu terlihat dari kiprahnya untuk memanfaatkan forum diplomasi regional seperti Forum on China and Africa Cooperation (FOCAC). Forum diplomasi tersebut dipergunakan China sebagai sarana untuk menyosialisasikan pemahaman mengenai persepsi yang 
sama dalam bidang keamanan kepada para pemimpin negara di Afrika. Melalui forum FOCAC, China juga dipandang berhasil membuat narasi persetujuan terkait Sino-African. Secara khusus, hal tersebut dianggap sebagai pengulangan yang dilakukan oleh China agar di antara negara-negara berkembang saling mendukung satu sama lain dalam menciptakan kemakmuran bersama. China berhasil membawa para pemimpin Afrika menuju sebuah dialog yang dalam prosesnya sangat memungkinkan China untuk lebih lanjut dapat membantu pembangunan di Afrika dan memainkan peran penting dalam perdamaian dan keamanan di Afrika.

Salah satu bagian yang menarik dari isi buku ini adalah penjelasan mengenai peran China dalam Joint Comprehensive Plan of Action (JCPOA). China berupaya menggambarkan dirinya sebagai negara yang aktif, konstruktif, dan juga dapat bertanggung jawab atas agenda global termasuk terkait pemberian sanksi terhadap dalam isu nuklir Iran. Padahal Iran merupakan mitra perdagangan yang penting bagi China. Peran China dalam pemberian sanksi memang dianggap penting, namun juga kurang dipahami dengan baik oleh China. Daniel Johanson dkk berusaha menangkal anggapan bahwa China selalu terlihat berkuasa lebih di panggung global. Padahal terkadang, China juga muncul sebagai negara dengan pertimbangan yang kurang matang ketika menghadapi beberapa situasi tertentu.

Penjelasan berikutnya terkait hubungan China dan Jepang yang berdampak terhadap hubungan China dengan beberapa negara di Asia termasuk Indonesia. Setidaknya ada dua hal penting yang menjadi sorotan hubungan luar negeri China dan Jepang yang berdampak terhadap negara di Asia. Pertama, keseimbangan kekuasaan yang dimiliki oleh China dan Jepang serta dampak yang dimainkan oleh lingkungan eksternal. Adanya ketidakpercayaan antara kedua negara dalam masalah keamanan dan militer yang bersumber dari faktor sejarah di masa lalu. Di samping itu, terjadi peningkatan kerja sama dalam bidang sosial dan ekonomi yang disoroti sebagai upaya menuju hubungan yang lebih harmonis di masa depan. Kerja sama dianggap sebagai titik terang yang dapat menyebabkan hubungan China dan Jepang menjadi lebih baik. Tetapi, sengketa teritorial di kawasan Asia Tenggara, Taiwan, serta ketidakpastian yang melekat dalam politik luar negeri Amerika juga berpotensi menjadikan hubungan kedua negara menjadi renggang. Interaksi bilateral yang sedang terjadi antara China dan Jepang menunjukkan bukti bahwa dalam jangka pendek, China dan Jepang kemungkinan akan melanjutkan keterlibatan kerja sama ekonomi dan proses perimbangan kekuatan militer. Namun, dalam jangka panjang, China lebih siap untuk memiliki keunggulan kekuatan daripada Jepang. China dinilai tumbuh berkembang lebih cepat dalam bidang ekonomi, militer dan juga didukung faktor demografis. Apalagi jika Amerika menarik keterlibatan aktif di Timur Asia, kemungkinan besar China akan menjadi pemain paling dominan terutama dalam bidang militer.

Akan tetapi, ada dua permasalahan yang dapat mempengaruhi dan menghambat kerja sama bilateral dalam bidang ekonomi antar kedua negara. Pertama yakni defisit perdagangan dan kedua adalah dinamika politik yang berperan dalam proyek ekonomi multilateral. Meski perdagangan bilateral tetap kuat, dinamika politik yang kompleks dan kompetitif dapat menjadi penghambat utama keharmonisan kedua negara. China dan Jepang tentu memang menjadi bagian dari negara terkemuka yang berpartisipasi di sejumlah organisasi regional, seperti APEC, ASEAN+3, dan ASEAN Regional Forum. Namun, negara-negara yang menjadi bagian dari mitra kerja sama masing-masing negara patut mendapat perhatian lebih karena dapat menghambat hubungan antar kedua negara yang didasarkan pada proyeksi kepentingan politik. 
Bagi China, akan semakin mudah melakukan ekspansi hubungan luar negeri dengan negara-negara di Asia. Hal itu dipengaruhi oleh kemampuan China dalam image building sebagai negara yang memiliki kekuatan untuk rising power dengan menerapkan new security concept dalam menjalin hubungan dengan negara lain. Maksud dari new security concept yang digunakan China adalah untuk memproyeksikan diri tidak hanya sebagai tetangga yang baik bagi negara lain, tetapi juga sebagai mitra yang baik (Alunaza at el, 2018: 3). Selain rising power, julukan yang melekat pada China sebagai Peaceful Rise juga menggambarkan situasi dan pengaruh yang dibawa oleh China dalam kerangka hubungan luar negerinya dengan negara-negara di dunia. China dijelaskan mampu mendekati negara lain yang didukung dengan modal dari sektor ekonomi yang sangat besar, teknologi yang begitu maju, dan sumber daya manusia yang sangat berpengaruh. China juga dikenal sebagai negara memiliki kekuatan engagement sebagai interaksi strategis untuk mempengaruhi perilaku politik suatu negara melalui comprehensive establishment dan peningkatan kontak hubungan dengan negara-negara target di berbagai bidang seperti diplomatik, militer, dan ekonomi yang dilakukan China terdapat Amerika Latin, Afrika, dan negara-negara Asia (Musfiroh et al, 2020: 198).

Tidak dapat disangkal bahwa China memang memainkan peran yang sangat besar dalam politik luar negerinya dengan negara-negara di dunia. Namun, dalam konteks perubahan agenda, perspektif baru, dan perdebatan yang sedang terjadi, buku ini tidak secara spesifik menjelaskan perubahan agenda baru dalam politik luar negeri China. Termasuk tidak dengan jelas menunjukkan perspektif baru sebagai respons banyak negara atas perdebatan terkait hubungan China dengan banyak negara dalam konstelasi politik global. Penyunting hanya menjelaskan dinamika hubungan China dengan Jepang, hubungan China dengan Afrika dalam proyek bantuan kereta cepat dan road belt initiative, serta beberapa deskripsi mengenai sejarah dan hubungan luar negeri China dengan negaranegara Amerika Latin.

Dimensi transnasional melalui penjelasan kebijakan luar negeri China dalam studi Sino-Japanese relations serta diplomasi publik sebagai bagian dari gerakan ofensif China merupakan kelebihan tersendiri yang dapat dijabarkan penyunting dengan baik. Meski demikian, penjelasan dalam buku hasil suntingan Daniel Johanson, Jie Li, dan Tsunghan $\mathrm{Wu}$ ini layak mendapatkan perhatian dari para penstudi dan pemerhati politik luar negeri. Meski konten buku ini tidak bercerita secara lengkap tentang perubahan agenda kebijakan luar negeri China, pembahasan dalam buku ini sangat mudah dipahami dengan diksi yang tidak terlalu rumit. Agar penjelasan menjadi lebih komprehensif, buku ini perlu dilengkapi dengan penjelasan mengenai image building, new security concept, rising power, peaceful rise, comprehensive establishment, dan kemampuan engagement China yang berhubungan dengan tren dalam politik luar negara China itu sendiri.

\section{Daftar Pustaka}

Alunaza, Hardi. et al. (2018). The Strategic Cooperation between Indonesia and China Under Jokowi's Foreign Policy towards Global Maritime Diplomacy. Jurnal Hubungan Internasional Indonesia, 1 (1), pp. 1-18

Musfiroh \& Alunaza, H. (2020). Strategi Engagement China terhadap New Zealand dan Australia Melalui Kerja Sama Bantuan Trilateral di Asia Pasifik. Jurnal Ilmiah Hubungan Internasional, 16 (2), pp. 195-209. 